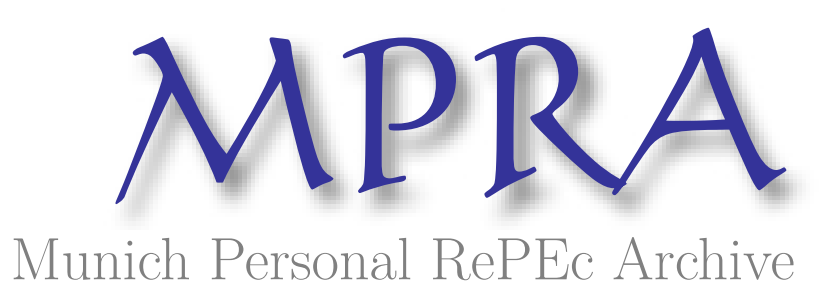

\title{
Intergovernmental Transfers and Own Revenues of Subnational Governments in Nigeria
}

Taiwo, Kayode

23 September 2020

Online at https://mpra.ub.uni-muenchen.de/104374/

MPRA Paper No. 104374, posted 03 Dec 2020 07:20 UTC 


\title{
Intergovernmental Transfers and Own Revenues of Subnational Governments in Nigeria
}

\author{
Kayode Taiwo*
}

\begin{abstract}
The paper explores the effect of the unconditional intergovernmental transfers on own revenues of subnational governments in Nigeria. Models of intergovernmental transfers predict that transfers from the central government to subnational governments amount to a tax reduction on the residents of subnational jurisdictions as transfers lead to a lower effort in own revenue mobilisation by subnational governments. This study employs the instrumental variables (IV) model to establish the impact of annual variation in intergovernmental transfers on own revenues of subnational governments. The study reveals that states depend mainly on transfers from the federal government to run their operations; and, transfers to secondlevel administrative units, states in Nigeria crowd out own revenues. A 1 percent rise in transfer leads to about 0.64 percent reduction in own revenues per capita. Also, the drive for the collection of revenues nosedives during the election years. The findings are anchored on the political economy of decentralisation in Nigeria.
\end{abstract}

Keywords. Federalism, Intergovernmental transfer, revenue, subnational government, instrumental variables JEL Classification: H29, H71, H77

\footnotetext{
* Núcleo de Investigação em Políticas Económicas e Empresariais (NIPE), School of Economics and Management, Universidade do Minho, Portugal and Department of Economics, Adekunle Ajasin University, Nigeria. Email: kayode.taiwo@hotmail.com. I thank the participants at the Workshop on Discussing 21st Century Economies: From Fiscal Federalism to Regional Policies at the Universidade do Minho and the participants at the presentation to the Public Economics Unit, Faculty of Economics and Management, the University of Kassel for their helpful comments and suggestions. I also thank my advisors for their useful comments and pieces of advice.
} 


\section{Introduction}

The decentralised governance arrangement engenders a system of cooperative and interdependent governments. This arises out of the need to share resources among levels of government making up the federation. The revenue assignment under federalism ${ }^{1}$ sometimes gives much power over revenue-raising to the central government as compared with subnational governments for many reasons, which include the capacity for revenue collection. The result is that the revenues of subnational governments are barely enough to cope with their constitutional responsibilities. This, apart from externalities and/or equity consideration, necessitates the grant-giving function of the central government. However, grants do have an income effect on the grant-receiving governments. It raises the income of the recipient government, and the government could behave like any rational individual in its revenue and expenditure choices. In other words, the recipient government could reduce effort in its revenue mobilisation since it is cheaper to receive transfers than to embark on revenue-raising within its jurisdiction.

The models of intergovernmental transfers under a decentralised governance arrangement have predicted that federal transfers amount to a reduction of tax liabilities for residents of subnational jurisdictions as transfers will crowd out local revenues (Bradford \& Oates, 1971a, 1971b). Empirical studies of the effect of transfers on own revenues of subnational jurisdictions under decentralisation in developed countries have shown that transfers do result in a lower tax effort by subnational governments (Zhuravskaya, 2000; Buettner and Wildasin, 2006), including a low level of efficiency in resource usage (Kalb, 2010). Notwithstanding this empirical finding, studies have shown that subnational governments in developed countries generate higher tax revenues as a proportion of transfers when compared with developing countries where the subnational governments depend on the central government for almost 70-95 percent of operating revenues. ${ }^{2}$

Though decentralisation has been touted as a means through which some of the challenges of development in developing countries could be overcome (Faguet, 2008; Smoke et al., 2013), warnings by Prud'homme (1995) and Reinikka and Svensson (2004) have shown that decentralisation does not automatically solve development problems in developing countries due to the motives behind decentralisation vis-à-vis developed countries. The efficiency consideration is not the primary motive behind decentralisation in many developing countries (Bardhan, 2002), thereby giving rise to local capture, corruption, weak state because

\footnotetext{
${ }^{1}$ Federalism, as used here, is not based on the constitutional declaration but the structure of the public sector (see Oates, 1972). Thus, federalism and decentralisation are used interchangeably.

2 The figure for the Philippines is 85 percent (Troland, 2016), 91 percent for Tanzania (Masaki, 2018), 90 percent for Lesotho, 88 percent for Uganda, 69 percent for Ghana, and 60 percent for Malawi (Fjeldstand and Heggstad, 2012).
} 
of excessive fragmentation, poor fiscal capacity, debt crisis, among other challenges. More importantly, what appears to be decentralisation in some developing countries is nothing but fragmentation. This arises out of the need to please local elites or ethnic champions. Thus, transfers to subnational governments are used as directed by the elites but not for capacity building and provision of services. Under such circumstances, transfers will crowd out own revenues of subnational governments as those that are denied essential services will revolt against or evade tax payment.

Subnational governments in Nigeria fit into the above picture. In view of this, Nigeria is an ideal setting to test whether transfers crowd in or crowd out own revenues of subnational governments. The focus of this study is on the second-level administrative units, which are known as states. This study focuses on the second level of administration because own revenues for local government areas are neither reported nor published. They receive transfers from the federal government, but they are less accountable for many reasons. ${ }^{3}$ States are not entirely different from local governments in the management of transfers. While transfers bear almost all operating costs of local governments, states are dependents on federal transfers in the range of 75-95 percent of their budgeted revenues. ${ }^{4}$

This paper is the first to empirically examine the causal effects of federal transfers on own revenues of state governments in Nigeria using panel data. Besides, there is a need to study the Nigerian situation in the face of existing studies on some sub-Saharan African economies with a similar structure to Nigeria (Morgues and Benin, 2012; Caldeira and Rota-Graziosa, 2014; Masaki, 2018). The collection of taxes rests on fiscal capacity and administrative competence (Besley and Persson, 2013) which are dependent on federal transfers to state governments. Federal transfers are endogenous to own revenues of subnational governments because transfers may be used to provide essential services that may yield higher own revenues to subnational governments. The study employs the instrumental variables (IV) model due to the endogeneity issue to identify the causal effect. Thus, we use distance to Federal Capital Territory (FCT) and fragmentation (the number of local government areas in each state) as instruments for federal transfers. The empirical findings reveal that transfers crowd out own revenues of subnational governments in Nigeria. The empirical finding is anchored on corruption5 (Prud'homme, 1995; Reinikka and Svensson, 2004; Brollo et al., 2013) which leads to vote buying during elections (Khemani, 2015), high level of informality of subnational economies and weak tax administration (Joseph-Raji, 2015), resource dependence (Caselli and

\footnotetext{
${ }^{3}$ Local governments in Nigeria are the ideal example of what Reinikka and Svensson (2004) referred to as local capture. Many local governments have no published account of operations for many years.

${ }^{4}$ Except Lagos State, almost all other states generate less than 25 percent of their annual budgets. See Table 1.

${ }^{5}$ Corruption is a major issue at subnational levels in Nigeria due to the circumstances surrounding the evolution of states and local government areas. Many subnational past executives are facing cases of corruption in courts. This is made worse by the constitutional provision which guarantees protection from criminal offence while in office. This period enables them to tinker with evidence that could have nailed them during prosecution.
} 
Michaels, 2013), and partial fiscal decentralisation which imposes limits on revenue-raising powers of the subnational governments and causes them to depend on the federal government for a huge chunk of their budgeted revenues (Borges et al., 2014).

This paper is organised as follows. Section two reviews the literature on theoretical and empirical issues on the relationship between transfers and own revenues of subnational governments. Section three is devoted to the evolution of subnational units and the drive for own revenues in Nigeria. Section four treats the empirical model, estimation strategy, and data. In section five, the results are discussed. The study is concluded in section six.

\section{Intergovernmental transfers and local revenue generation: A literature survey}

The raison d'être of a multi-level government is to bring government closer to the people, particularly where there are substantial socio-cultural differences among the people and improves efficiency in the choice of programs (Bahl and Bird, 2008; Bird and Smart, 2002; Oates, 1972, 1999). For this objective to be realised, an essential component of the federal system of government is intergovernmental transfers. This exists under the federal government arrangement for many reasons. Among other reasons, intergovernmental transfers are made to support the operation of subnational governments, especially where this might have been impossible without such support (Oates, 1972). It makes possible the development of local capacity, helps local governments to focus on governance and promotes even development among the subnational units (Faguet, 2008). Where there is an imbalance between the expenditure responsibilities and the revenueraising capacity of subnational governments, intergovernmental transfers are allocated to bridge the gap. More importantly, it helps in the attenuation of the differences in local fiscal capacity. By and large, fiscal decentralisation improves efficiency in the allocation of resources (Oates, 2007).

The substitutability of intergovernmental transfers for local revenues makes local fiscal autonomy a difficult objective under a decentralised governance arrangement. The good intention behind intergovernmental transfers is threatened by issues such as excessive stimulative spending effect of transfers by subnational governments much more than income from own revenue sources, a phenomenon dubbed "flypaper effect" (Hine and Thaler, 1995); fiscal illusion, where both the revenue and the cost of government are not transparent, and taxpayers do not perceive the true cost of services provided in taxes by the government (Hine and Thaler, 1995); tax export, whereby a jurisdiction shifts its tax burden to a richer neighbouring jurisdiction (Musgrave, 1999). Also, intergovernmental transfers without a hard budget constraint encourage 
excessive spending, which may result in debts and engender macroeconomic issues. Thus, local revenue mobilisation is germane to a robust federal system (Bird and Smart, 2002).

For all the issues raised above, it appears there is a negative impact of unconditional intergovernmental transfers on the efficiency of resource use and own revenue mobilisation at the subnational level under a multi-level government. This follows from the logic that "if a community required to finance its own public programs through taxation, residents are more likely to weigh the benefits of the programs against its actual costs (Oates, 1972 p.13)." This requires the local residents to be circumspect of their choice of programs through their votes because of the tax implication. The early theoretical treatise on the crowd-out effect of unconditional central government transfers was developed by Bradford and Oates (1971a, 1971b). They posit that unconditional transfers by the central government amount to individual tax reduction at the subnational units which discourage rather than encourage own revenue mobilisation by subnational governments. The lump-sum unconditional transfers have an income effect on the grant-receiving governments (Bradford and Oates, 1971a). Wilde (1968) advances a similar view that the local government can use the general grant in a manner which makes it appears like tax cuts for local residents. It does have a stimulating effect on the expenditure decisions of the grant-receiving governments under a median-voter arrangement. This perverts the system of intergovernmental fiscal relations under the decentralisation arrangement as it opposes the principle that spending jurisdictions should be responsible for their finance (Musgrave, 1999). This leads to an inefficient choice of programs and spending because an average median voter wants more services but less burden in tax payment.

The theoretical postulation of Bradford and Oates (1971a, 1971b) is supported by some empirical studies of the impact of intergovernmental transfers on own revenue mobilisation by subnational governments in developed countries. In a study on the US, Buettner and Wildasin (2006) conclude from their extensive research on municipalities across the US that transfers from the central government crowd out local revenues of municipalities. Zhuravskaya (2000) submits that intergovernmental fiscal relations among levels of government provide no incentives to local governments to increase own revenue mobilisation in Russia. Without local ownership through an aggressive own resource generation, expenditure efficiency may be difficult to achieve under decentralised governance arrangement (Bird and Smart, 2002). Indeed, Kalb (2010) finds that intergovernmental transfers produce a negative effect on the cost-efficiency of municipalities in Germany. This is mainly due to the "exploitation of fiscal common." Sobel and Crowley (2014) report that federal grants in the US result in an increase in state and local future tax income in the region of 40 cents per dollar received in the previous year. Unlike the earlier studies, they find that grants 
from the central government lead to an increase in revenue mobilisation efforts of subnational governments. Zhang (2013) finds that intergovernmental transfers, in various forms, stimulate local revenue efforts of Chinese local governments. Lago-Peñas (2008) concludes that Spanish municipalities react to a reduction in grants by increasing own revenues.

A few studies have been conducted on developing countries with mixed results. Based on a study conducted on Ghana, Morgues and Benin (2012) conclude that, notwithstanding the incentive scheme embedded in unconditional intergovernmental transfers, the transfer scheme crowds out own revenues of district governments. On the other hand, Caldeira and Rota-Graziosa (2014) find that revenues from the customs allocated to local governments unconditionally lead to an increase in own revenue generation by local governments in the case of Benin. A similar effect is reported on transfers to local governments in the Philippines by Troland (2016). He anchors the effect on the issues of fixed cost and credit constraints associated with the capacity for revenue collection, which intergovernmental transfers can help to surmount. Also, Masaki (2018) concludes on a study in Tanzania that intergovernmental transfers crowd in local revenues, especially in rural areas.

\section{Subnational governments and the drive for own revenues in Nigeria}

\subsection{The political economy of decentralisation in Nigeria}

The modern federal system of government in Nigeria has its root in the Nigerian pre-Independence Constitution of 1946. At that time, Nigeria was a federation of three regions, including the Colony of Lagos. The federal structure of three regions was maintained until 1963 when the fourth region was created. The political crises after the attainment of the republic in 1963 led to the introduction of states in 1967. In 1967, under the military government, Nigeria had 12 states. Phillips (1991) posits that "military governments tend to be unitary, regardless of whether the country is constitutionally a federation." Of course, the coming of the military into the running of the affairs of government brought in some degree of centralisation in the federal system, which has not been wholly eliminated. In what followed, the existing structure for revenue generation for regions/states had to be switched in favour of the federal military government (Table A1).

With the central allocation of resources and political powers under the military system of government, usually associated with corruption and arbitrariness, the coming of the military did not bode well for the Nigerian federal system of government. The creation of states and local government areas, therefore, became means of political settlements and perpetuating selves in power among the top echelon of the military. The patterns 
of state and local government creation gave no attention to the economic survival of states but political considerations. This occurs because the economic resources for running different regions before the coming of the military government had been brought under the federal military government and thus shared by military fiats. In other words, expenditures chosen in some states are paid for by other states through taxes and other federal incomes raised from those states. Thus, Nigeria went from a country of three regions in 1960 to 36 states, a semi-autonomous state, Federal Capital Territory (FCT) and 774 local government areas in 1996. ${ }^{6}$ Following the incessant fragmentation of states and local governments, the revenue allocation formula had to be regularly adjusted. Between 1946 and 2004, Nigeria has had 18 different vertical revenue allocation formulae.? Political considerations have largely informed the changes in vertical revenue allocation formula rather than sound economic criteria with the intention of weaning the subnational governments off dependence on transfers from the federal government.

The current vertical allocation formula has been in use since 2004. The formula allocates 52.68 percent, 26.72 percent, and 20.60 percent to the federal government, state governments, and local governments, respectively (column 12, Table A2). The vertical formula is applied to all distributable federal revenues after some statutory deductions have been made. These special deductions include 13 percent derivation fund to be shared among the oil-producing states in the country in addition to a share of distributable 26.72 percent allocation to all states. ${ }^{8}$ The existence of the vertical allocation formula necessitates the existence of a horizontal sharing formula for subnational units in Nigeria (Tables A3). On the whole, all intergovernmental transfers based on the afore-mentioned formula attach no condition for the grantreceiving governments.

The fragmented states and local government areas are rather conduits for channelling state's resources into the hands of a few elites at the state and local government levels. This gives room for local capture (Reinikka and Svensson, 2004) as the centrally allocated resources for local development are cornered by the elites. Of course, the emerging pattern of the development of states is largely influenced by the rent-seeking structure that forms the basis of their creation. Though the military had left since 1999, there seems to be a carry-over of the military structure as observed by Phillips (1991). The incomplete decentralisation that was birthed under the military system has now become a major problem for the states under the democratic government. The states depend mostly on hand-outs from the federal government mainly because the

\footnotetext{
${ }^{6}$ The states are further grouped into regions for political purposes. There are six regions: North Central, North East, North West, South South, South East, and South West. While North West has 7 states, South East comprises of 5 states. All other regions have 6 states.

7 See Phillips (1991) for a detailed discussion of pre-1990 federal finance issues in Nigeria. See Table A2.

\& The 13 percent derivation fund is no longer limited to oil but also revenues from other profitable mineral resources. The basis for sharing the 13 percent derivation fund is the number of oil wells in each oil-producing state. Those states benefiting from this special fund are located mainly in the South-South region, and this account for the high revenue profile of the region in Figure 2.
} 
federal government funds come largely from resource rents. The cheap sources of federal revenues make it difficult for the federal government to complete the decentralisation of the federation. Furthermore, the incentive behind the creation of states and local governments in Nigeria generates a chain effect by making the states and local government areas mere appendages of the federal government. The funds that they get through transfers from the federal government are frittered away through corruption and wastage, thereby failing to put in place structures that are relevant to their survival. This has culminated in the present situation of poor own revenue effort that characterised the subnational economies.

\subsection{Intergovernmental transfers and own revenue mobilisation at the subnational level in Nigeria}

Before 1966, Nigeria had a robust federal system that encouraged interregional competition that enabled some modest development. A regional system of government that recognised differences in the economic resources and structures of the constituent units of the federation was in place until six years after independence. With Decree No. 1 of 1966 announcing the proscription of the constitution and vesting the power to make laws for and running of the federation in the Supreme Military Council (SMC), and Decree No. 2 of 1966 through which the abolition of federalism was enforced, the journey on the road to centralisation was embarked upon. ${ }^{9}$ The ripple effect of these decrees, though the suspension of federalism was later reversed with Decree No. 9 of 1966, is yet to abate. The federal system remains unitary even after the demise of the military regime.

In a healthy federal system of government, devolution of economic powers is sacrosanct. Subnational governments can use the resources at their disposal to generate funds to run their governments. This is not the case for Nigeria. Many of the states in Nigeria are tied to the apron's string of the federal "donor" as dependent on the intergovernmental transfers is in the range of 75 percent to 95 percent of their total revenues in a fiscal year as shown in Table 1 and Figure 1. Own revenues as a share of gross transfers range between 15 percent to 22 percent. The total tax income of the subnational governments is a small fraction of the federation's gross domestic product (GDP) as observed by Bahl and Bird (2008). As shown in Table 1, both transfers from the federal government and own revenues of subnational governments respond to the political situation. For general election years, 2007 and 2011, own revenues of states nosedived while transfers from the federal government went up.

See LeVan, A. C. (2015) for discussion on dictatorship and development in Nigeria. 
Table 1: Revenues and transfers to states (billions of naira), 2007 - 2013

\begin{tabular}{lrrrrrrr}
\hline \multirow{2}{*}{ Transfer/Revenue } & \multicolumn{7}{c}{ Fiscal Year } \\
\cline { 2 - 8 } & 2007 & 2008 & 2009 & 2010 & 2011 & 2012 & 2013 \\
\hline Total Revenue & $2,204.45$ & $2,935.66$ & $2,271.03$ & $2,238.14$ & $2,529.37$ & $2,384.75$ & $2,432.07$ \\
Gross Transfer & $1,976.81$ & $2,602.36$ & $1,930.00$ & $1,912.59$ & $2,256.78$ & $2,108.41$ & $2,095.63$ \\
Net Transfer & $1,905.95$ & $2,532.80$ & $1,865.05$ & $1,826.49$ & $2,123.16$ & $1,953.39$ & $1,981.65$ \\
Own Revenue & 298.50 & 402.87 & 405.98 & 411.65 & 406.21 & 431.36 & 450.41 \\
OR as \% of Net Transfer & 15.66 & 15.91 & 21.77 & 22.54 & 19.13 & 22.08 & 22.73 \\
OR as \% of Gross Transfer & 15.10 & 15.48 & 21.04 & 21.52 & 18.00 & 20.46 & 21.49 \\
OR as \% of Total Revenue & 13.54 & 13.72 & 17.88 & 18.39 & 16.06 & 18.09 & 18.52 \\
\hline \hline
\end{tabular}

Notes: Total revenue is the sum of net transfer and reported own revenue (OR) for all states in each year. OR is expressed as a percentage of net transfer, gross transfer, and total revenue. Source: Author's computation.

The military enacted the Nigerian 1999 Constitution. According to Section 44 (3) of the 1999 Constitution of Nigeria, ownership of all land economic and natural resources is vested in the Nigerian federal government. The section states that "the entire property in and control or all minerals, mineral oils and natural gas in, under or upon any land in Nigeria or in, under or upon the territorial waters and the Exclusive Economic Zone of Nigeria shall vest in the Government of the Federation..." This provision limits economic activities of states and revenues they could generate, leading to incomplete fiscal federalism (Table A1) and makes subnational governments mere appendages of the central government in Nigeria. Besides, for taxes that fall under the jurisdictions of both the federal and state governments such as PAYE (PIT), Capital Gain Tax, and Stamp Duties, the power to legislate remains that of the federal government, while the administration of the taxes is shared with states (Phillips, 1997). Based on the horizontal revenue-sharing formula in place, some states in the country are better off in terms of transfers from the federal government despite contributing too little to the federation account. ${ }^{10}$

Sales Tax, a significant source of revenue, was initially under the control of the state governments. It had to be applied on commodity sales in their jurisdictions to raise tax revenues. But, under the military government in January 1994, the Value Added Tax (VAT) was introduced. The states were made to surrender their powers over the Sales Tax to the federal government. The consequence of this is that the federal government makes states to depend on a share of the VAT revenues. ${ }^{11}$ The current vertical sharing arrangement of VAT revenues is 15 percent, 50 percent, and 35 percent for the federal government, state governments, and local governments, respectively. The incentive built into the revenue allocation formula could be a significant

\footnotetext{
${ }^{10}$ The federation account is a "Distributable Pool Account" that houses all the federal government incomes that will be ultimately shared by all the three tiers of government.

${ }^{11}$ Though Sales Tax and VAT are not the same, the states were made to stop the imposition of sales tax for a share of federally collected revenues from VAT. Note also that states do not collect VAT.
} 
determinant in the drive for subnational governments to generate own revenues to fund their programs (Bird and Smart, 2002). This appears to be the case for Nigeria.

Figure 1: A bar chart displaying the average real total revenue, gross transfer, net transfer and own revenue of states by year (billions of naira), 2007 - 2013

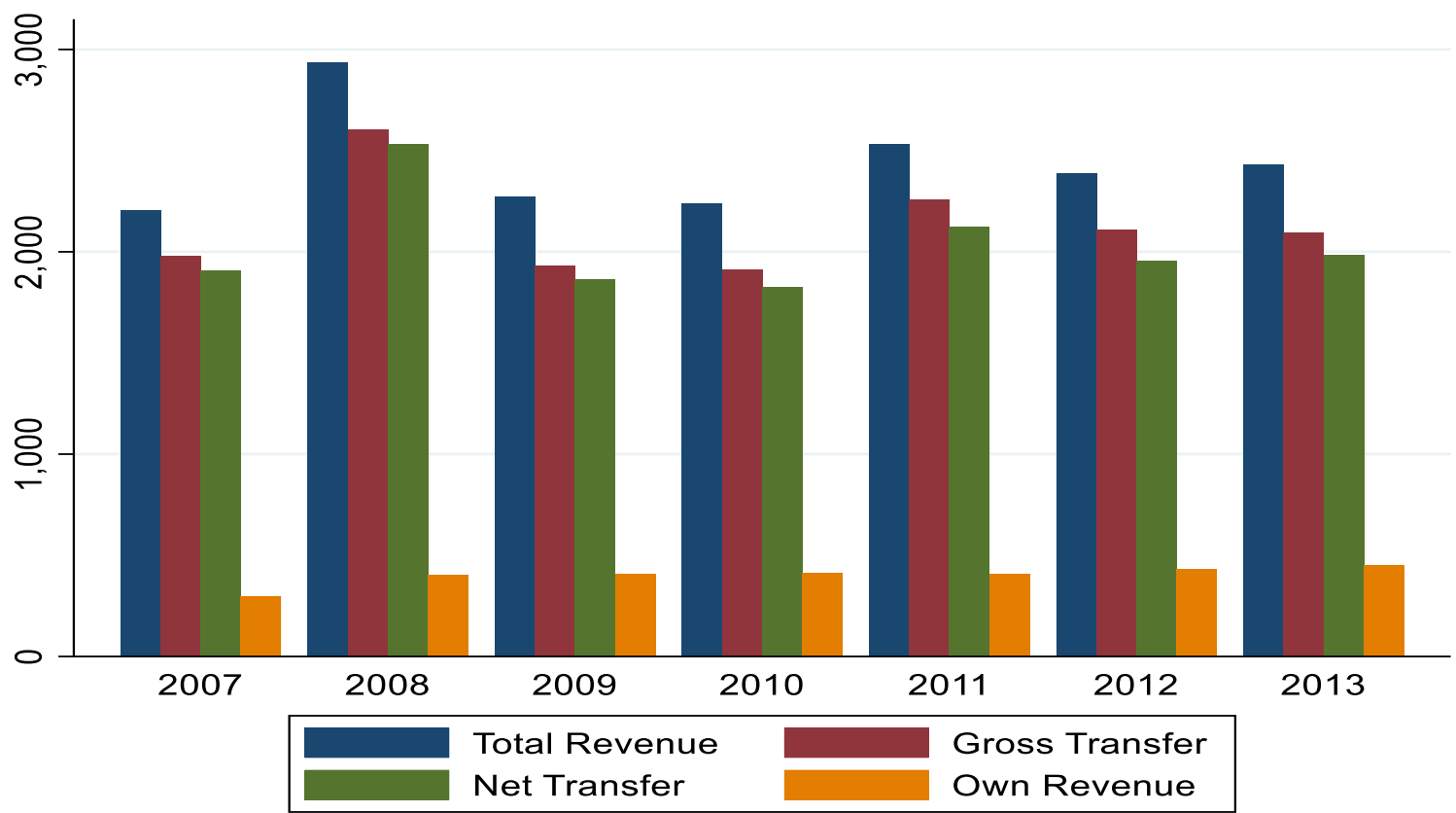

Source: Author's computation

With the extant horizontal sharing formula (Table A3), the states where fewer economic activities are taking place have a share of the VAT revenues that is almost the same with states where economic activities are substantially large. This happens because equality, population, and landmass largely determine transfers to states. The derivation principle has started to receive attention since 2002. ${ }^{12}$ This reflects in the revenue profiles of states in the South-South region where the hydrocarbon economy of Nigeria is located (Figure 2). The effect of the derivation principle is rather insignificant in terms of motivation for own revenues by subnational governments in Nigeria. The states are still generally less active economically and depend on allocations from the federal government. According to Musgrave (1999 p. 164), "there is ... the principle that spending jurisdictions should be responsible for their finance. This follows as a matter of efficiency in program choice and as a matter of equity, interpersonal as well as interjurisdictional." The violation of this principle engenders moral hazard and tax exporting as in the Nigerian case.

${ }_{12}$ This follows the Supreme Court's ruling in respect of revenues derived from sales of mineral resources which are in some states of the federation. 
Figure 2: A bar chart displaying the average real own revenue, net transfer, gross transfer, and total revenue of states by regions (billions of naira), 2007 - 2013

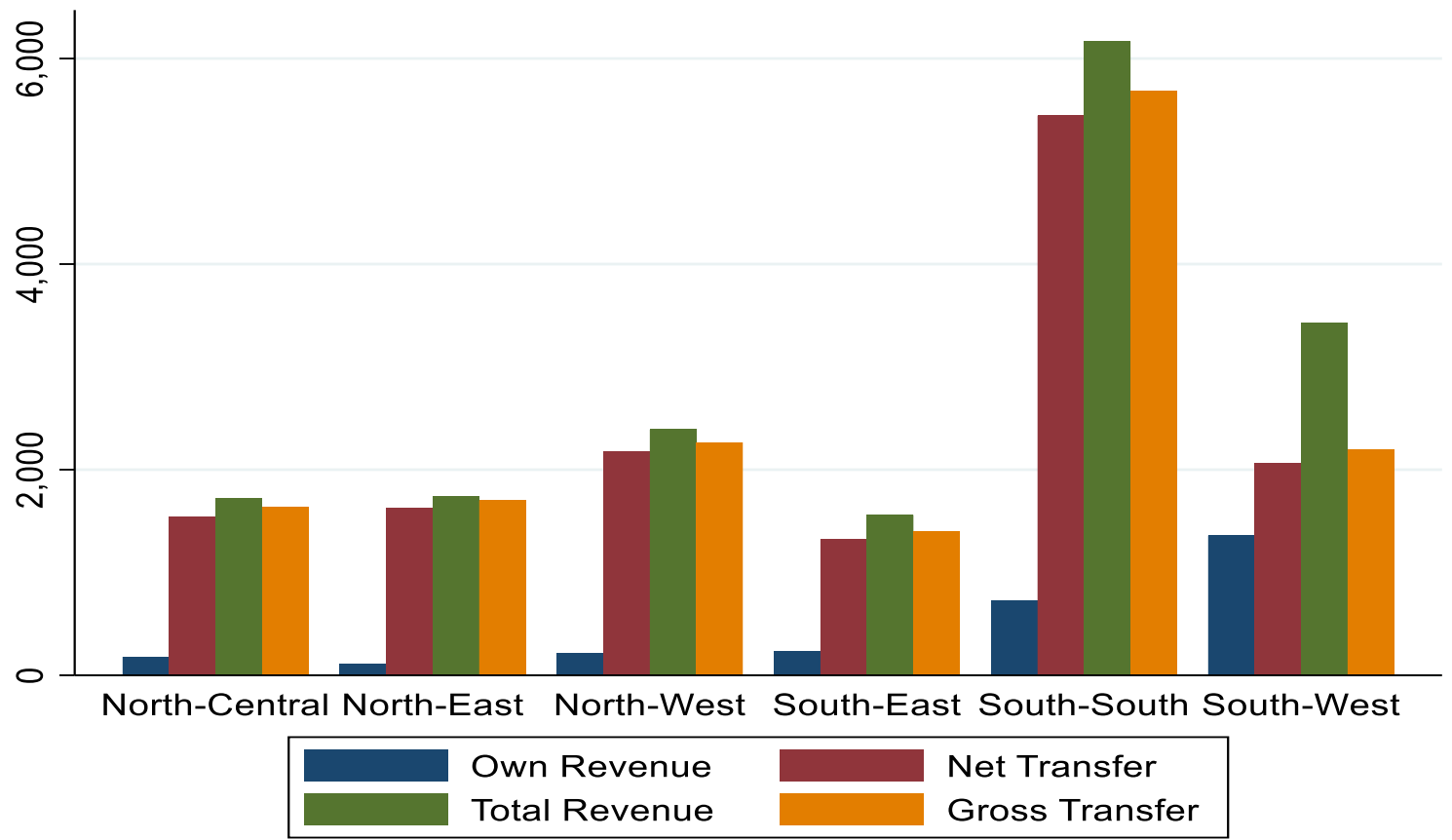

Notes: The states in the South-South region are mainly oil-producing. One of the states in the South-West and two in the South-East regions belong to the group of the oil-producing states. While North-West comprises of seven states, South-East has five states. All other regions have six states. Source: Author's computation.

Table 2: Registered Taxpayers in Nigeria, 2016

Type of Tax

Number of registered

taxpayers

Number of active

Percent active

taxpayers

(percentage of total)

\begin{tabular}{lrrr}
\hline Personal income tax & 716,057 & 14,823 & 1.95 \\
Company income tax & $1,003,010$ & 56,329 & 5.62 \\
Value added tax & $1,505,831$ & 77,082 & 5.12 \\
\hline
\end{tabular}

Note: Data collected by the International Survey on Revenue Administration (ISORA). Source: IMF, 2018.

Nigeria has one of the lowest revenue-to-GDP ratios among its peers; its 5.3 percent of GDP in revenues for 2016 is below the sample average of 22 percent of GDP for its peers (IMF, 2018). The non-oil income tax is insignificant. This is borne out of the effect of the nation's significant oil resources on the federal government revenues. The oil resources create a cheap source of income for the federal government on which the entire federation relies. The information in Table 2 above depicts the poor administration of taxes that fall under the jurisdiction of the federal government of Nigeria. It appears subnational governments mirror the federal government in their efforts for revenue mobilisation. 
The assigned sources of revenues to states (Table A1) are reported under five classifications apart from unconditional transfers from the federal government and investment incomes: Pay as You Earn (PAYE) which are deductible from workers' salary at the source, direct assessment for self-employed individuals, road taxes for road users, and other taxes such as Withholding Tax, Capital Gain Tax and Stamp Duties, and revenues from services by ministries, departments and agencies (MDAs) of state governments (Figure 3). According to data from the Joint Tax Board (JTB), of the 10 million registered personal income taxpayers (PIT) for all states in Nigeria including the FCT, 46 percent are in the tax net of Lagos State alone (IMF, 2018). The registered taxpayers are far below the nation's workforce of 77 million in 2015. This implies that only about 13 percent of the labour force are taxpayers. However, many of the states are civil service states where there are few private establishments. The inability to bring workers in formal employment in their states into their tax nets points to the issue of weak tax administration bedevilling states and the effects of the incentive scheme built into the unconditional intergovernmental transfers in Nigeria. The subnational governments are plagued by lack of capacity for tax collection, poor tax policies, corruption in tax administration, and limited tax bases (Joseph-Raji, 2015). The challenges are made worse by a high degree of informality in all the subnational economies.

Due to political factors surrounding the creation of states, states pay less attention to developing their sources of internal revenues. Apart from the poor incentive scheme in the horizontal allocation formula, the existing constitution is rather market-perverting instead of being market-preserving. The constitution does not ensure a healthy competition among subnational governments of the Nigerian state but makes them dependent on the federal government for survival. States compete on how to increase their shares of the "national cake" rather than working on expanding the cake. There is a real moral hazard issue in revenue sharing among subnational governments in Nigeria. The subnational governments are indulged in weak revenue-generating efforts. Thus, they face a soft budget constraint with all the negative implications for the national economy. 
Figure 3: Classification of own revenue sources of state governments in Nigeria

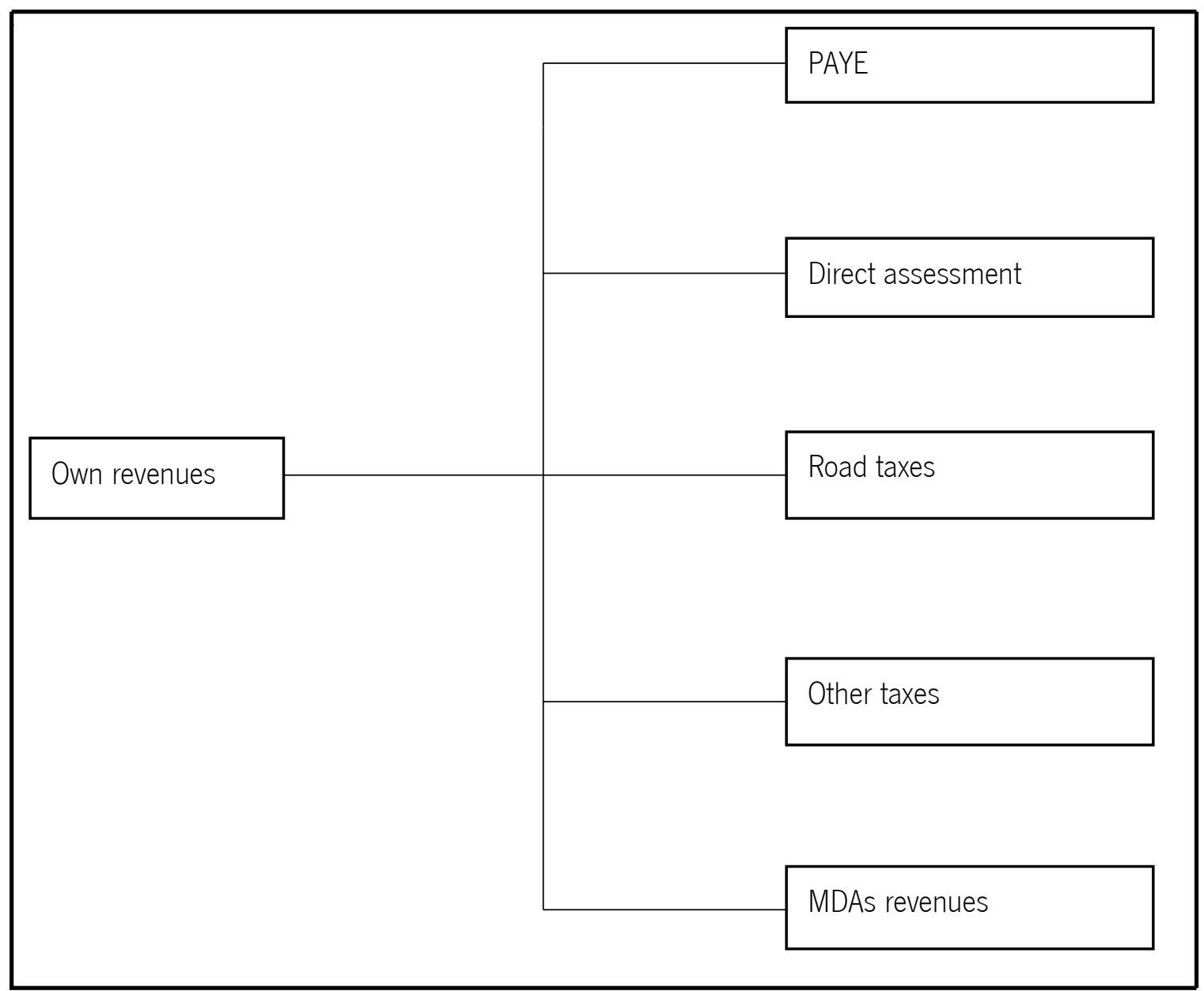

Notes: PAYE means Pay as You Earn. It is a tax on personal income deductible from salary at the source. MDAs refers to ministries, departments and agencies of state governments. They render services that generate income for states. Source: Author's compilation.

\section{Methodology}

\subsection{The empirical model and estimation strategy}

This study follows the empirical model of Caldeira and Rota-Graziosi (2014) and Masaki (2018) to empirically test the relationship between intergovernmental transfers and own revenues of subnational governments in Nigeria.

$$
\text { Own revenue }_{i, t}=\beta \text { Transfer }_{i, t}+\gamma \mathbf{X}_{i, t}+\alpha+\xi_{i, t}
$$


Equation (1) relates own revenues per capita to change in intergovernmental transfers per capita and a set of covariates to identify the effect of intergovernmental transfers on own revenues where $i$ and $t$ index state $i$ and year $t$, respectively. Own revenue represents the real revenues from taxes and fees raised by a subnational government per capita local currency (naira) log transformed. At the same time, Transferis the real intergovernmental transfers due to a state per capita local currency log transformed. The $\mathbf{X}_{i, t}$ represents several covariates (Population density, Election year, Agricultural loan, Children population, Luminosity, Fragmentation, Educationally developed state, Distance) which help to lessen the effect of omitted variable bias in the model. $\beta$ and $\gamma$ are vectors of parameters to be estimated; $\xi_{i, t}$ is the error term while $\alpha$ is the homogenous intercept term for each state $i$ when the model is estimated using pooled ordinary least squares (OLS).

Economic theory predicts that subnational governments will reduce efforts in generating own revenues in the face of a constant and steady flow of transfers from the central government. In order to estimates the relationship in the case of states in Nigeria, this study employs some covariates in the models which are defined below. Population density is the number of people per square kilometre in a state. It is log transformed. This is expected to significantly influence own revenues of subnational governments in Nigeria (Mogues and Benin, 2012). However, the expected sign of the coefficient of this variable is not clear as the own revenue generation depends mainly on the efficiency of states in tax administration. Election year is a dummy variable that takes 1 for the election year, and 0 otherwise. Politics influences decisions in tax administration at the subnational level. Executives in power may use tax policies to sway decisions of voters during the period of elections (Khemani, 2015). Population under 15 years of age is Children population in each state. A large population of children in a state presents both threat and opportunity. It represents an opportunity where the state can mobilise resources to harness their talents, but a threat where the state is unable to meet their needs for personal development. The burden of meeting the needs of the young population in order to channel their talents to productive use does require a state to be able to raise substantial tax revenues.

Many subnational economies in Nigeria are predominantly agrarian. The value of loans channels into the agricultural sector is assumed a significant determinant of the size of subnational economies. The value of loans divided by the population of each state gives the Agricultural loan per capita. The value of the logtransformed variable can also significantly influence how much is raised in own revenues by subnational governments. The brightness of visible lights from space at night is termed Luminosity. The night lights can help to measure income, which is a measure of the gross domestic products (GDP) of economies, especially 
in economies characterised by a high level of informality like the Nigerian subnational economies (Henderson et al., 2011, 2012). Under each state is the third level of administration. These are known as local government areas in Nigeria. This is captured with the variable tagged Fragmentation, and it is log transformed. The number in each state influences political as well as economic matters including total transfers to each state because they are statutorily entitled to a share of the federal income. More local government areas may result in a lower effort in pursuing own revenue mobilisation.

The level of literacy matters to states' economies. States with a high level of human capital development are expected to have higher own revenues. This study uses a dichotomous variable based on the classification of states by a Nigerian government establishment. States categorise as Educationally developed states (EDS) are coded 1, otherwise for states ELDS.13 Distance to the administrative capital of Nigeria is another variable in this study. States that are closer to the central administrative capital are expected to receive higher transfers from the central government (Gisselquist et al., 2016; Masaki, 2018). The signs associated with coefficients of Agricultural loan, Luminosity, and EDS should be positive while those of Election year, Fragmentation, and Distance are expected to be negative. The signs associated with coefficients of Population density and Children Population are however not definite.

Estimation of equation (1) begins with the implementation of ordinary least square (OLS). OLS exploits both within and between effects, but it is not as efficient as random effects (RE). When there are panel effects, RE is more efficient because it uses a matrix weighted average of within and between effects (Baltagi, 2013). A Breusch-Pagan Lagrangian Multiplier test (Breusch and Pegan, 1980) is implemented to select a better estimator between OLS and RE. The number of time-invariant variables in our model precludes the implementation of fixed effects. Many subnational governments lack the capacity to collect their own revenues. The flow of transfers from the federal government may be instrumental to the development of the capacity for own revenue collection at subnational levels (Besley and Persson, 2013; Troland, 2016; Masaki, 2018). In this case, there is a reason to suspect simultaneity and reverse causality between own revenues of states and transfers from the central government leading to the problem of endogeneity. In other words, a correlation between regressors and residual errors is suspected. Thus, the instrumental variables (IV)/twostage least squares (2SLS) model may be more appropriate in estimating equation (1).

An IV/2SLS model requires at least a variable that satisfies two major conditions: exogeneity and relevance. Exogeneity requires that the IV variable is not correlated with the residual error, while the relevance condition

\footnotetext{
${ }^{13}$ There are more states in the group of Educational Less Developed States (ELDS): Adamawa, Bauchi, Bayelsa, Benue, Borno, Cross Rivers, Ebonyi, Gombe, Jigawa, Kaduna, Kano, Kastina, Kebbi, Kogi, Kwara, Nassarawa, Niger, Plateau, Rivers, Sokoto, Taraba, Yobe, and Zamfara.
} 
requires the variable to be correlated with the endogenous regressor. Without satisfying these conditions, an IV model breaks down. This can be tested using a battery of tests such as the overidentification test, and underidentification test, among others. In this study, Fragmentation and Distance in level are deemed to satisfy the conditions for the validity of instruments in the IV model. This is based on the economics of revenue sharing in Nigeria and the empirical finding of established scholars. Gisselquist et al. (2016) and Masaki (2018) have found that distance from the national capital is an exogenous variable that influences intergovernmental transfers from the central government to subnational units. Also, the number of local government areas or political units ${ }^{14}$ in a state can influence the intergovernmental transfers to that state, but not the amount that can be raised in own revenues. This position emanates from the view that politicians allocate resources tactically for political gains (Johansson, 2003; Veiga 2012; Kauder et al., 2016). Electoral consideration can bring the issue of fragmentation into sharing of intergovernmental transfers.

The dependence of own revenues on past own revenues and transfers introduces dynamic relationship into the variables of interest. Besides, the inclusion of lagged variables among the regressors invalidates the exogeneity assumption of the independent variables. Thus, implementation of another model becomes necessary. A dynamic model in the form of system generalised method of moments (SGMM) may be more appropriate in addressing our concerns. Equation (2) is stated below:

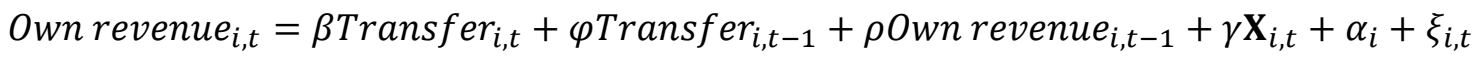

$$
\begin{aligned}
& i=1, \ldots \ldots, N, \quad t=1, \ldots \ldots, T
\end{aligned}
$$

where $i$ and $t$ are as described in equation (1). The parameters of interest to be estimated in equation (2) are $\beta, \varphi, \rho$ and $\gamma . \alpha_{i}$ is the state-specific effect of state $i$, while $\xi_{i t}$ is the error term. Equation (2) is vital for this study since own revenues may be persistence over the years. The own revenues of any subnational government may be dependent on the past level of both own revenues and intergovernmental transfers. More so, own revenue effort is factored into the horizontal revenue sharing. ${ }^{15}$ Thus, equation (2) helps to capture the effects of the past own revenues and intergovernmental transfers by including not just the lagged

\footnotetext{
${ }^{14}$ Political units such as electoral wards, senatorial districts, and federal representatives' districts are deemed to be valid instruments in respect of the issue here given the strategic consideration of politicians in allocation of public funds. However, this study only uses the number of local government areas. Besides, unlike developed countries where the expansion of municipalities is used to promote development and increase revenues (Hatfield and Kosec, 2013 and Baskaran et al., 2016), Nigerian states are not free to increase the number of their municipalities. The current local government areas in each state in Nigeria were created under the military to increase transfers to some states and entrench itself in power. In developing countries, political considerations trump efficiency criterion in decentralisation decisions (Bardhan, 2002). See also footnotes 4 and 6, and Section 3.

${ }_{15}$ This may be valid in principle than in practice. Local government areas are allocated transfers without data on own revenues. By and large, this does not invalidate the use of the dynamic model as other considerations are valid. See notes under Table A3.
} 
value of own revenues but also the contemporaneous and lagged values of intergovernmental transfers. It is therefore required that the sum of $\beta$ and $\varphi$ should be greater than zero for transfers to crowd in own revenues. In view of the foregoing, it may be more appropriate to use a dynamic model.

The inclusion of a lagged dependent variable among regressors generates two challenges. One, the lagged dependent variable is weakly exogenous, and it correlates with state-specific error and the lagged random error; and, the persistence effect of the initial condition of the dependent variable in a short panel. The generalised method of moments (GMM), which was introduced by Arellano and Bond (1991) can handle the problems. Arellano and Bond (1991) exploit the orthogonality condition between the lagged dependent variable and the random error to generate instruments to address the problem. Blundell and Bond (1998) extend previous studies by Arellano and Bond (1991) and Arellano and Bover (1995). They exploit imposition of restrictions on the distribution of the initial values of the dependent variable, which allow the use of lagged differences of the dependent variable as instruments in the level equations in SGMM. The SGMM rest on the absence of autocorrelation, at least autocorrelation of order 2 (AR2). Autocorrelation of order 1 (AR1) can occur because of the correlation of the lagged dependent variable with the state-specific error. This study implements the two-step GMM estimator with finite sample correction in standard errors (Windmeijer, 2005). The instruments are handled according to Roadman (2009a, 2009b).

\subsection{Data and descriptive statistics}

The data for this study is longitudinal data with cross-sectional and time dimensions on states in Nigeria. This study focuses on states because information on own revenues of the local government areas is not available. The data spans a period of seven years, from the year 2007 to the year 2013. The shortness in the panel is due to the need to use the DMPS-OLS nightlights data which is not available after 2013 to proxy sizes of subnational economies and the non-availability of own revenue data for states before 2007. Besides, the Nigerian economy has slowed down since 2014, which can confound the relationship between federal transfers and own revenues. All monetary variables are adjusted for the change in the time value of money using the Nigerian composite consumer price index (CCPI). The data on transfers is a monthly data in its original form because intergovernmental transfers are made monthly from incomes of the federal government from the previous month. On the other hand, own revenue data is released quarterly. Some states do not make their own revenue data available quarterly but only at the end of the year. Thus, the data is aggregated yearly for both transfers and own revenues over the year. All other data, including the dichotomous variables, distance and fragmentation, is constructed annually. Luminosity is the annual 
average visible lights from version 4 DMSP-OLS night-time lights series. The information is obtained using ArcMap to process the DMSP-OLS data archived on the website of the National Oceanic and Atmospheric Administration (NOAA). The data is available from the year 1992 to the year 2013. A subset of the observational time series data is used in this study.

Correlation analysis of the regressors reveals that Fragmentation correlates with Children population. The coefficient is in the region of 0.66 . All other variables have lower correlation coefficients. Also, we test for the presence of autocorrelation in the data using the Wooldridge test for autocorrelation in panel data (Drucker, 2003; Wooldridge, 2010), the test confirms the presence of autocorrelation by rejecting the null hypothesis of no serial autocorrelation with an F statistic of 16.38 at 1 percent level of significance. This study exploits White's test for heteroskedasticity (White, 1980). ${ }^{16}$ The result of the test indicates that the null of homoskedasticity is rejected with a chi-square of 83.41 at 1 percent level of significance. The regressions are clustered over the states in order to address the problems of autocorrelation and heteroskedasticity (Wooldridge, 2010). The clustered robust standard error relaxes the assumption of no correlation in the errors by allowing correlations within clusters but not between clusters.

Table 3: Descriptive statistics for the years 2007-2013

\begin{tabular}{lrrrr}
\hline \hline Variable & \multicolumn{1}{c}{ Mean } & \multicolumn{1}{c}{ Std. Dev. } & \multicolumn{1}{c}{ Min } \\
\hline Own revenue & $2,068.34$ & $2,928.11$ & 120.27 & $19,492.75$ \\
Transfer & $14,622.48$ & $12,915.05$ & $5,392.26$ & $101,232.70$ \\
Population density & 340.10 & 466.03 & 40.77 & 3008.09 \\
Agricultural loan & 50.67 & 45.89 & 0.59 & 276.41 \\
Children population & 178.03 & 78.81 & 71.29 & 479.28 \\
Luminosity & 2.85 & 4.74 & 0.03 & 21.35 \\
Fragmentation & 21.34 & 7.06 & 8 & 44 \\
Distance & 524.19 & 197.56 & 156 & 957 \\
Election year & 0.32 & & 0 & 1 \\
Educationally developed state & 0.36 & & 0 & 1 \\
\hline \hline
\end{tabular}

Notes: Data is sourced from the Central Bank of Nigeria (CBN), Joint Tax Board (JTB), National Bureau of Statistics (NBS), NOAA's National Centre for Environmental Information, and Office of the Accountant General of the Federation (OAGF). N = 250, the number of states is 36, and $T=7$. Own revenue, transfer and agricultural loan are in per capita term. Children population is in '000. Distance is the distance to the Federal Capital Territory (FCT). All dummy variables are generated by the author based on publicly available information. Source: Author's computation.

\footnotetext{
${ }_{16}$ The test for heteroskedasticity is limited to White's test because of the number of time-invariant variables in the model.
} 


\section{Results}

\subsection{Empirical results}

The results of the econometric estimation are presented in this section. The results are in Table 4 below. Based on the strength of arguments presented in Section 4.1, the analysis will focus primarily on the results from the IV/2SLS and SGMM models. Nevertheless, the results of the OLS and RE models in columns 1-2 are briefly presented. The coefficient of Transfer is positive, but it is not statistically significant for OLS and RE models in columns 1-2. This may be due to the issues of endogeneity and reverse causality discussed in the previous section. Results in columns 1-2 are almost the same. On comparison, the result of the Breusch-Pagan Lagrangian Multiplier test (with the null hypothesis that there is no panel effect) to compare the efficiency and consistency of OLS and RE does confirm a panel effect. Thus, the result indicates that the RE model is more efficient with a Chi-squared statistic of 314.01 at 1 percent level of significance. Under RE model in column 2, Log agricultural loan, Luminosity, and Educationally developed state are positively correlated with Own revenue, while Election year and Log fragmentation are negatively correlated with Own revenue. The RE model has a good fit with between R-squared of 63 percent. The Rho of 0.72 indicates that 71 percent of the variation is due to differences across panels.

From the IV/2SLS model in column 3, a 1 percent rise in Transferwill lead to a 0.64 percent fall in Own revenue per capita. This indicates transfer dependency among the subnational governments in Nigeria. Election year is a period of vote buying in many developing countries (Khemani, 2015), including Nigeria, with policies being designed to favour the electorate because of inadequate investment in public services. As such, Own revenue mobilisation will nosedive by 24 percent in any period of the election. About 18 percent rise in own revenues can be attributed to 1 percent change in Luminosity of any state while being an Educationally developed state will account for 61 percent rise in own revenue per capita. The model has an R-squared of 0.46; this implies the model explains 46 percent of the variation in Own revenue per capita. The Kleibergen-Paap rk Lagrangian Multiplier statistic for the underidentification test with a Chi-squared of 6.32 and a p-value of 0.04 shows that the excluded instruments are valid and relevant. The model is identified; and, the excluded instruments are correlated with the endogenous regressor. The KleibergenPaap rk Wald F statistic of 15.05 does confirm that the instruments are not weak based on Staiger and Stock's (1997) rule of thumb that an F statistic above 10 indicates that weak identification is not a problem. ${ }^{17}$ Thus, the joint null hypothesis that the instruments are valid cannot be rejected. The Hansen J statistic for

${ }^{17}$ Having identified two problems of autocorrelation and heteroskedasticity in our data, we cannot expect that the error term from our regression will be independent and identically distributed which necessitates the clustering of our regression over the states. This invalidates the Cragg-Donald Wald F statistic reported in ivreg2. Hence, we rely on the Kleibergen-Paap rk Wald F statistic and adopt Staiger and Stock's (1997) rule of thumb. 
the overidentification test of all instruments indicates that the excluded instruments are correctly excluded with a Chi-squared of 0.41 and a p-value of 0.52 .

Table 4: Net intergovernmental transfers and own revenues of subnational governments in Nigeria

\begin{tabular}{|c|c|c|c|c|c|c|}
\hline \multirow{2}{*}{ Variable } & (1) & (2) & (3) & (4) & (5) & (6) \\
\hline & OLS & RE & IV/2SLS & OLS & RE & SGMM \\
\hline Transfer & $\begin{array}{c}0.3393 \\
(0.2215)\end{array}$ & $\begin{array}{c}0.2032 \\
(0.1256)\end{array}$ & $\begin{array}{l}-0.6439^{*} \\
(0.3675)\end{array}$ & $\begin{array}{l}0.3199^{\star *} \\
(0.1346)\end{array}$ & $\begin{array}{l}0.3199^{* *} \\
(0.1346)\end{array}$ & $\begin{array}{c}0.2058 \\
(0.2473)\end{array}$ \\
\hline Log transfer (t-1) & & & & $\begin{array}{l}-0.3143^{\star * *} \\
(0.1088)\end{array}$ & $\begin{array}{l}-0.3143^{* * *} \\
(0.1088)\end{array}$ & 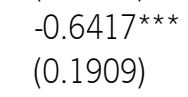 \\
\hline Log own revenue (t-1) & & & & $\begin{array}{l}0.8320^{\star * *} \\
(0.0439)\end{array}$ & $\begin{array}{l}0.8320^{* * *} \\
(0.0439)\end{array}$ & $\begin{array}{l}0.7445^{\star * \star} \\
(0.1924)\end{array}$ \\
\hline Log pop. density & $\begin{array}{l}-0.0293 \\
(0.1549)\end{array}$ & $\begin{array}{c}0.1327 \\
(0.1820)\end{array}$ & $\begin{array}{l}-0.1241 \\
(0.1851)\end{array}$ & $\begin{array}{c}0.0227 \\
(0.0423)\end{array}$ & $\begin{array}{c}0.0227 \\
(0.0423)\end{array}$ & $\begin{array}{c}0.1137 \\
(0.2513)\end{array}$ \\
\hline Election year & $\begin{array}{l}-0.2376^{\star * \star} \\
(0.0729)\end{array}$ & $\begin{array}{l}-0.1736^{\star \star *} \\
(0.0522)\end{array}$ & $\begin{array}{l}-0.2716^{\star * *} \\
(0.0690)\end{array}$ & $\begin{array}{l}-0.1131 \\
(0.0717)\end{array}$ & $\begin{array}{l}-0.1131 \\
(0.0717)\end{array}$ & $\begin{array}{l}-0.1208 \\
(0.8715)\end{array}$ \\
\hline Log agricultural loan & $\begin{array}{c}0.1237^{*} \\
(0.0641)\end{array}$ & $\begin{array}{c}0.0458^{*} \\
(0.0271)\end{array}$ & $\begin{array}{c}0.0371 \\
(0.0908)\end{array}$ & $\begin{array}{c}0.0066 \\
(0.0176)\end{array}$ & $\begin{array}{c}0.0066 \\
(0.0176)\end{array}$ & $\begin{array}{l}-0.0691 \\
(0.1361)\end{array}$ \\
\hline Children population & $\begin{array}{c}0.0037 \\
(0.0024)\end{array}$ & $\begin{array}{c}0.0023 \\
(0.0016)\end{array}$ & $\begin{array}{l}-0.0011 \\
(0.0027)\end{array}$ & $\begin{array}{l}-0.0003 \\
(0.0004)\end{array}$ & $\begin{array}{l}-0.0003 \\
(0.0004)\end{array}$ & $\begin{array}{l}-0.0023 \\
(0.0016)\end{array}$ \\
\hline Luminosity & $\begin{array}{l}0.0734^{* *} \\
(0.0358)\end{array}$ & $\begin{array}{c}0.0468^{*} \\
(0.0261)\end{array}$ & $\begin{array}{l}0.1662^{* * *} \\
(0.0379)\end{array}$ & $\begin{array}{c}0.0190 \\
(0.0113)\end{array}$ & $\begin{array}{r}0.0190^{\star} \\
(0.0113)\end{array}$ & $\begin{array}{r}0.0448^{*} \\
(0.0241)\end{array}$ \\
\hline Log fragmentation & $\begin{array}{l}-0.8846^{* *} \\
(0.4079)\end{array}$ & $\begin{array}{l}-0.8348^{* *} \\
(0.3466)\end{array}$ & $\begin{array}{l}-0.6306 \\
(0.5167)\end{array}$ & & & \\
\hline Edu. developed state & $\begin{array}{l}0.5915^{\star *} \\
(0.2351)\end{array}$ & $\begin{array}{c}0.4883^{*} \\
(0.2743)\end{array}$ & $\begin{array}{c}0.4773^{*} \\
(0.2532)\end{array}$ & & & \\
\hline Log distance & $\begin{array}{l}-0.0596 \\
(0.1252)\end{array}$ & $\begin{array}{c}0.0266 \\
(0.1299)\end{array}$ & $\begin{array}{l}-0.0138 \\
(0.1570)\end{array}$ & & & \\
\hline $\mathrm{R}^{2}$ & 0.60 & 0.63 & 0.46 & 0.86 & 0.98 & \\
\hline Rho & & 0.71 & & & & \\
\hline Breusch-Pagan test & & $314.08^{* * *}$ & & & & \\
\hline KP rkLM stat (pv) & & & 0.04 & & & \\
\hline AR1 (pv) & & & & & & 0.05 \\
\hline AR2 (pv) & & & & & & 0.11 \\
\hline Hansen stat (pv) & & & 0.52 & & & 0.58 \\
\hline No of instruments & & & & & & 30 \\
\hline N & 250 & 250 & 250 & 215 & 215 & 215 \\
\hline
\end{tabular}

Significance levels: ${ }^{*}: 10 \%,{ }^{* *}: 5 \%,{ }^{* * *}: 1 \%$. Clustered robust standard errors at the state level are in parentheses. The dependent variable is Own Revenue per capita log transformed, while Transfer is the net transfer per capita log transformed. Edu. developed state refers to Educationally developed state. Log pop. density is the log of population density. Results in columns 1-3 are estimates of equation (1) using various estimators, while the results for equation (2) are shown in columns 4-6. The instruments for the 2SLS in column 5 are Fragmentation and Distance in level and the Kleibergen-Paap Wald rk F statistic for weak identification test is 15.05. For column 6, Fragmentation and Distance in level including year dummies are used as IV-style instruments. pv is a p-value. KP rk LM stat refers to Kleibergen-Paap rkLagrangian Multiplier statistic. AR1 and AR2 are ArellanoBond test for AR1 and AR2 respectively in first difference. All models in Table 4 are estimated with year dummies. Source: Author's computation. 
The results of the dynamic model are reported in columns 4-6 in Table 4. Notwithstanding the inappropriateness of the OLS and RE in estimating the dynamic model (especially when $T$ is short as in this study), they are needed to show the trend in the results from the estimators. The Breusch-Pagan Lagrangian Multiplier test does indicate that we cannot reject the null of no panel effect. Thus, the Rho of RE model in column 5 is 0 ; and, the coefficients of RE and OLS are the same. This points to the inappropriateness of both OLS and RE. The result from the SGMM model in column 6 confirms the IV/2SLS model in column 3.18 Transfer is not statistically significant, and the coefficient has a positive sign against our expectation. The lag of Transfer is negative and statistically significant. It implies that a year after receiving a 1 percent increase in transfers, the own revenues of subnational governments will fall by about 0.64 percent in per capita term. Since many subnational governments lack the capacity to collect own revenues efficiently, they get carried away with an increase in transfers in the following year that they abandon own revenue mobilisation. This confirms the transfer dependency alluded to earlier. The lag of Own revenue, the dependent variable is positive and statistically significant. This shows that the Own revenues are serially correlated over the period. Luminosity is positively correlated with Own revenue. The SGMM model has a Hansen statistic p-value of 0.58 and the number of instruments used is 30 . The model neither suffer from autocorrelation of order 1 nor 2 .

\subsection{Robustness checks}

A set of regressions is estimated to test the robustness of the main regression results from the models. The same data used in the main regression is used for robustness checks except for the data on Transfer. The gross transfer is what is due to a state at any time money is shared among levels of government in Nigeria. However, what states ultimately get is the net transfer which has been used in the main regressions in Table 4. Because subnational governments cannot commit directly to foreign borrowings on their own, states apply for foreign loans with a guarantee from the federal government that creditors will be paid as at when due. This is done to control the propensity of subnational governments to accumulate debts that may lead to a macroeconomic crisis for the nation. So, the federal government deducts due repayments at the source from states' allocations at any time money is shared among levels of government.

\footnotetext{
${ }_{18}$ Fragmentation and Distance in level and Fragmentation and Distance including year dummies are used as instruments for models in columns 3 and 6 , respectively. Though Fragmentation is a valid instrument in our model, it may have a limited use with respect to studies on developed countries (see Hatfield and Kosec, 2013; Baskaran et al., 2016).Also, two steps GMM estimation with the robust option in xtabond2 is specified to apply Windmeijer (2005) for the correction of standard errors of the estimator. Also, the GMM instruments are lagged by 1 .
} 
Table 5: Gross intergovernmental transfers and own revenues of subnational governments in Nigeria

\begin{tabular}{|c|c|c|c|c|c|c|}
\hline \multirow{2}{*}{ Variable } & (1) & (2) & (3) & (4) & (5) & (6) \\
\hline & OLS & RE & IV/2SLS & OLS & RE & SGMM \\
\hline Transfer & $\begin{array}{c}0.3582 \\
(0.2244)\end{array}$ & $\begin{array}{c}0.2602^{* *} \\
(0.1176)\end{array}$ & $\begin{array}{l}-0.6497^{\star} \\
(0.3658)\end{array}$ & $\begin{array}{l}0.3511^{* *} \\
(0.1512)\end{array}$ & $\begin{array}{c}0.3511^{* *} \\
(0.1512)\end{array}$ & $\begin{array}{c}0.1928 \\
(0.2787)\end{array}$ \\
\hline Log transfer (t-1) & & & & $\begin{array}{l}-0.3473^{\star * \star} \\
(0.1272)\end{array}$ & $\begin{array}{l}-0.3473^{\star * \star} \\
(0.1272)\end{array}$ & $\begin{array}{l}-0.6119^{\star \star \star \star} \\
(0.2171)\end{array}$ \\
\hline Log own revenue (t-1) & & & & $\begin{array}{l}0.8332^{\star * *} \\
(0.0449)\end{array}$ & $\begin{array}{l}0.8332^{\star \star \star} \\
(0.0449)\end{array}$ & $\begin{array}{l}0.7188^{\star * \star} \\
(0.1964)\end{array}$ \\
\hline Log pop. density & $\begin{array}{l}-0.0281 \\
(0.1538)\end{array}$ & $\begin{array}{c}0.1332 \\
(0.1790)\end{array}$ & $\begin{array}{l}-0.1236 \\
(0.1872)\end{array}$ & $\begin{array}{c}0.0218 \\
(0.0424)\end{array}$ & $\begin{array}{c}0.0218 \\
(0.0424)\end{array}$ & $\begin{array}{c}0.1010 \\
(0.2585)\end{array}$ \\
\hline Election year & $\begin{array}{l}-0.2384^{* \star *} \\
(0.0725)\end{array}$ & $\begin{array}{l}-0.1725^{\star \star *} \\
(0.0520)\end{array}$ & $\begin{array}{l}-0.2690^{* \star *} \\
(0.0698)\end{array}$ & $\begin{array}{l}-0.1200^{*} \\
(0.0707)\end{array}$ & $\begin{array}{l}-0.1200^{*} \\
(0.0707)\end{array}$ & $\begin{array}{c}0.2290 \\
(0.7634)\end{array}$ \\
\hline Log agricultural loan & $\begin{array}{c}0.1243^{*} \\
(0.0631)\end{array}$ & $\begin{array}{c}0.0450^{*} \\
(0.0272)\end{array}$ & $\begin{array}{c}0.0386 \\
(0.0893)\end{array}$ & $\begin{array}{c}0.0075 \\
(0.0178)\end{array}$ & $\begin{array}{c}0.0075 \\
(0.0178)\end{array}$ & $\begin{array}{l}-0.0628 \\
(0.1323)\end{array}$ \\
\hline Children population & $\begin{array}{c}0.0037 \\
(0.0024)\end{array}$ & $\begin{array}{c}0.0026 \\
(0.0016)\end{array}$ & $\begin{array}{l}-0.0011 \\
(0.0027)\end{array}$ & $\begin{array}{l}-0.0003 \\
(0.0004)\end{array}$ & $\begin{array}{l}-0.0003 \\
(0.0004)\end{array}$ & $\begin{array}{l}-0.0021 \\
(0.0014)\end{array}$ \\
\hline Luminosity & $\begin{array}{c}0.0713^{*} \\
(0.0365)\end{array}$ & $\begin{array}{c}0.0422 \\
(0.0262)\end{array}$ & $\begin{array}{l}0.1673^{\star * \star} \\
(0.0375)\end{array}$ & $\begin{array}{c}0.0188 \\
(0.0114)\end{array}$ & $\begin{array}{c}0.0188 \\
(0.0114)\end{array}$ & $\begin{array}{l}0.0466^{\star *} \\
(0.0218)\end{array}$ \\
\hline Log fragmentation & $\begin{array}{l}-0.8732^{\star *} \\
(0.4037)\end{array}$ & $\begin{array}{l}-0.8359^{* \star} \\
(0.3438)\end{array}$ & $\begin{array}{l}-0.6586 \\
(0.5136)\end{array}$ & & & \\
\hline Edu. developed state & $\begin{array}{l}0.5943^{* *} \\
(0.2327)\end{array}$ & $\begin{array}{c}0.4961^{*} \\
(0.2728)\end{array}$ & $\begin{array}{c}0.4756^{\star} \\
(0.2565)\end{array}$ & & & \\
\hline Log distance & $\begin{array}{l}-0.0542 \\
(0.1238)\end{array}$ & $\begin{array}{c}0.0291 \\
(0.1280)\end{array}$ & $\begin{array}{l}-0.0249 \\
(0.1558)\end{array}$ & & & \\
\hline $\begin{array}{l}\mathrm{R}^{2} \\
\text { Rho }\end{array}$ & 0.60 & $\begin{array}{l}0.64 \\
0.71\end{array}$ & 0.46 & 0.86 & 0.98 & \\
\hline Breusch-Pagan test & & $314.26^{\star \star \star}$ & & & & \\
\hline KP rk LM stat (pv) & & & 0.04 & & & \\
\hline AR1 (pv) & & & & & & 0.06 \\
\hline AR2 (pv) & & & & & & 0.12 \\
\hline Hansen stat (pv) & & & 0.54 & & & 0.50 \\
\hline No of instruments & & & & & & 30 \\
\hline$N$ & 250 & 250 & 250 & 215 & 215 & 215 \\
\hline
\end{tabular}

Significance levels: ${ }^{*}: 10 \%,{ }^{* *}: 5 \%,{ }^{* * *}: 1 \%$. Clustered robust standard errors at the state level are in parentheses. The dependent variable is Own Revenue per capita log-transformed, while Transferis the gross transfer per capita log transformed. Edu. developed state refers to Educationally developed state. Log pop. density is the log of population density. Results in columns 1-3 are estimates of equation (1) using various estimators, while the results for equation (2) are shown in columns 1-3. The instruments for the 2SLS in column 3 are Fragmentation and Distance in level and the Kleibergen-Paap Wald rk F statistic for weak identification test is 15.68. For column 6, Fragmentation and Distance in level including year dummies are used as IV-style instruments. pv is a p-value. KP rk LM stat refers to Kleibergen-Paap rkLagrangian Multiplier statistic. AR1 and AR2 are ArellanoBond test for AR1 and AR2 respectively in first difference. All models in Table 5 are estimated with year dummies. Source: Author's computation.

Sometimes, the deduction may also be in respect of advances or overpayments made to states by the federal government. It may also be in respect of repayment for joint projects or local debts. When these deductions are made, states are credited with their balances which are referred to as the net transfers. The difference between gross transfers and net transfers could be huge for some states. The potential difference has enormous implications on the behaviour of the executives in power that are responsible for the 
management of states' finances. One of such possibilities is that where the gross transfer is enormous, it could encourage borrowings for anticipated transfers. And, such behaviour could discourage interest in own revenue mobilisation. By and large, the difference between gross transfers and net transfers could have a major impact on own revenue efforts of subnational governments. Thus, it is reasonable to use the gross transfer in place of the net transfer to check the robustness of the empirical findings under the same estimators as reported in Table 4.

The results of the regressions for the robustness checks are displayed in Table 5. The coefficient of Transfer is positive and statistically significant as shown in column 2, Table 5 under the RE model as against the result in column 2, Table 4. This may lead to a wrong conclusion that Transfer boosts own revenue generation at the subnational level in Nigeria, which may not hold for reasons stated in Section 4.1 such as endogeneity and reverse causality. The results for the OLS and RE in Table 5 are similar, but they are not efficiently estimated. Both IV/2SLS and SGMM models confirm our results in Table 4. For the IV/2SLS model, a 1 percentage rise in Transferwill lead to a drop in Own revenue by about 0.65 percentage in per capita. Election period will see a drop in the collection of revenues by subnational governments, while those states that invest more in human capital will see a rise in Own revenue in any year.

For the result in column 6, Table 5, the coefficient of the lag of Transfer at -0.61 is negative and statistically significant. The coefficient of Transfer of 0.19 is positive, but it is not statistically significant. The lag of Transfer is more negative. This further strengthens the validity of our result. According to the standard theory that the transfer from the central government is a reduction in the tax liability of economic agents at subnational jurisdictions. Thus, it is required that the coefficients of both Transferand lag of Transfershould be greater than zero for the central government transfers to subnational governments to have positive effects on own revenue mobilization under the SGMM model. However, the results of this study point to the contrary. This suggests that transfers are not being used as a launchpad to develop the capacity for own revenue generation at the subnational level in Nigeria.

\section{Conclusion}

One of the significant problems of incomplete fiscal decentralisation is that the central government assumes the role of the distributor of the commonwealth, whereby it shares its tax revenues and other incomes with subnational governments. The purpose of this may be to help subnational governments to develop the capacity for own revenue mobilisation. It turns out that it breeds transfer dependency and competition for 
more massive transfers, particularly where federal transfers form a significant chunk of revenues of subnational governments. In the case of Nigeria, subnational governments' dependence on transfers from the central government is in the region of 75 percent to 95 percent. It becomes almost impossible for subnational governments not to engage in borrowings to meet their unbridled consumption expenditures in anticipation of transfers. This makes them worry less about increasing own revenue mobilisation. The incentive scheme in ceaseless cheap transfers does not encourage the mobilisation of own revenues for developmental purposes and proper functioning of the states. The inability to wean the subnational governments off transfer dependency brings about the problem of bailouts. Bailouts are required when the subnational governments run into debt crises as experienced recently in Nigeria.

The result of this study shows there is a problem of transfer dependency among subnational governments. Transfers crowd out own revenues of subnational governments in Nigeria. Our finding is similar to the conclusion from Morgues and Benin (2012) on their study on Ghana. But, it differs from the results from the studies by Masaki (2018) and Caldeira and Rota-Graziosa (2014) on Tanzania and Benin, respectively. The revenue-sharing formula and the political economy of the creation of states are vital reasons for the behaviour of subnational governments in Nigeria. These factors discourage subnational governments in embarking on own revenue mobilisation as any state can expect large transfers with little or no effort. Though the transfers are expected to be used for the provision of services and capacity building for the development of states, it appears transfers are not used by states to build capacity for own revenue collection.

Besides, corrupt tax administration, mismanagement of own revenues, and misuse of transfers at the state level may have made it difficult to enforce the tax law and revenue collection at subnational levels in Nigeria. Taxpayers want to see the public goods provided for the taxes they pay. Where this is impossible, tax compliance becomes a problem. This may account for lack of interest in fulfilling the civic responsibility of tax payment on the part of the citizens of Nigeria. Additionally, the identified issues may have informed the needless buying of votes in the period of elections. The coefficient of Election year shows, including the information on Table 1 for the election years of 2007 and 2011, that revenue collection goes down during election years. Though the coefficient on the lag of own revenue indicates that the revenue collection is correlated, it appears the efforts are not enough. The states are not exploring all available options within the span of revenue assignment laws in revenue mobilisation (Table A1), notwithstanding that revenue assignment is skewed in favour of the federal government in Nigeria. There is a wide tax gap between what is collected in tax revenues and what can be collected in almost all states of the federation. This can be attributed to weak tax efforts and poor tax administration. 
By way of policy recommendation, there is a need to review the extant revenue assignment laws in Nigeria in favour of states. States should be able to use the resources in their jurisdictions for revenue mobilisation. They should also have some freedom to vary some tax rates within their jurisdictions where they share tax administration with the federal government. This will help to reverse the incomplete decentralisation arrangement and ensure that subnational governments are encouraged to be self-reliant by generating more own revenues. There is a need for appropriate fiscal institution to discourage transfer dependency among the subnational governments. Such arrangement will bring about positive competition among subnational governments not just in revenue mobilisation, but also in almost all facets of development. This should be followed with strict rules on revenue management and public debts ${ }^{19}$ at the subnational levels, particularly concerning access to money and capital markets. ${ }^{20}$ This requires the enforcement of the existing regulations in the Fiscal Responsibility Act (FRA) and the introduction of new rules.

\section{Reference}

Arellano, M., \& Bond, S. (1991). Some tests of specification for panel data: Monte Carlo evidence and an application to employment equations. The Review of Economic Statistics, 58(2), 277-297.

Arellano, M. \& Bover, O. (1995). Another look at the instrumental variable estimation of error-components models. Journal of Econometrics, 68(1), 29-51.

Bahl, R., \& Bird, R. (2008). Subnational taxes in developing countries: The way forward. Public Budgeting and Finance, 28(4), 1-25.

Baltagi, H. B. (2013). Econometric analysis of panel data, 5th ed. Hoboken, NJ: John Wiley \& Sons Ltd.

Bardhan, P. (2002). Decentralization of governance and development. Journal of Economic Perspectives, 164), 185-205.

Baskaran, T., Feld, L. P., \& Schnellenbach, J. (2016). Fiscal federalism, decentralization, and economic growth: A meta-analysis. Economic Inquiry, 54(3), 1445-1463.

Besley, T., \& Persson, T. (2013). Taxation and development. In A. Auerbach, R. Chetty, M. Feldstein, \& E. Saez (Eds.), Handbook of Public Economics (Vol. 5, pp. 51-110). Amsterdam: North-Holland.

Bird, R. M., \& Smart, M. (2002). Intergovernmental fiscal transfers: International lessons for developing countries. World Development, 306), 899-912.

Blundell, R., \& Bond, S. (1998). Initial conditions and moment restrictions in dynamic panel data models. Journal of Econometrics, 87(1), 115-143.

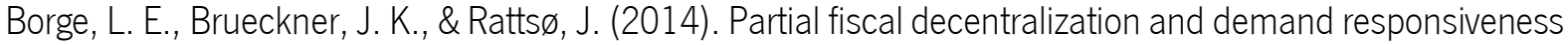
of the local public sector: Theory and evidence from Norway. Journal of Urban Economics, 80, 153163.

Bradford, D. F., \& Oates, W. E. (1971a). The analysis of revenue sharing in a new approach to collective fiscal decisions. The Quarterly Journal of Economics, 85(3), 416-439.

\footnotetext{
${ }_{19}$ The current arrangement where the approval of the Senate is sought for borrowings of subnational governments is not working. It has become a mere political tool for asserting political power between the executive governors and senators from their states. Besides, the scrutiny is not sincere and thorough.

${ }_{20}$ The banking reform of 2004, that restricts the participation of the subnational governments in the ownership of commercial banks, targets some forms of control at the subnational governments. Access to the capital market should be checked. Unchecked access to money and capital markets may discourage the need for own revenue mobilization. The unregulated use of debts by subnational governments amount to sharing control over monetary policy with the federal government.
} 
Bradford, D. F., \& Oates, W. E. (1971b). The economics of political decentralization: Towards a predictive theory of intergovernmental grants. American Economic Review, 61(2), 440-449.

Breusch, T. S., \& Pagan, A. R. (1980). The Lagrangian multiplier test and its applications to model specification in econometrics. The Review of Economic Studies, 471), 239-253.

Brollo, F., Nannicini, T., Perotti, R., \& Tabellini, G. (2013). The political resource curse. American Economic Review, 103(5), 1759-1796.

Caldeiraa, E., \& Rota-graziosi, G. (2014). The crowding-in effect of simple unconditional central grants on local own-source revenue: The case of Benin. Journal of African Economies, 23(3), 361-387.

Caselli, F., \& Michaels, G. (2013). Do oil windfalls improve living standards? Evidence from Brazil. American Economic Journal: Applied Economics, 5(1), 208-238.

Drukker, D. M. (2003). Testing for serial correlation in linear panel-data models. The Stata Journal, 3(2), 168-177.

Faguet, J. P. (2008). Decentralisation's effects on public investment: Evidence and policy lessons from Bolivia and Colombia. Journal of Development Studies, 44(8), 1100-1121.

Fjeldstad, O. H., \& Heggstad, K. (2012). Local government revenue mobilisation in Anglophone Africa. Working Paper-Chr. Michelsen Institute, (6), 1-34.

Gisselquist, R. M., Leiderer, S., \& Niño-Zarazúa, M. (2016). Ethnic heterogeneity and public goods provision in Zambia: evidence of a subnational "Diversity Dividend." World Development, 78(C), 308-323.

Hatfield, J. W., \& Kosec, K. (2013). Federal competition and economic growth. Journal of Public Economics, 97(C), 144-159.

Henderson, J. V., Storeygard, A., \& Weil, D. N. (2012). Measuring economic growth from outer space. American Economic Review, 102(2), 994-1028.

Henderson, V., Storeygard, A., \& Weil, D. N. (2011). A bright idea for measuring economic growth. American Economic Review, 101(3), 194-199.

Hines, J. R., \& Thaler, R. H. (2011). Anomalies: The flypaper effect. Journal of Economic Perspectives, 94), 217-226.

International Monetary Fund (IMF). (2018). Mobilizing tax revenues in Nigeria. Nigeria selected issues, IMF Country Report No. 18/64.

Inyang, E. O. (2013). The role and expectation of the members of revenue mobilization, allocation and fiscal commission on review of revenue allocation formula. Paper Presented at the Technical Session on the Review of Revenue Allocation Formula Held at the National Centre for Women Development, Abuja, pp. 1-26. Abuja, Nigeria.

Johansson, E. (2003). Intergovernmental grants as a tactical instrument: Empirical evidence from Swedish municipalities. Journal of Public Economics, 87(5-6), 883-915.

Joseph-Raji, G. A. (2015). The challenge of subnational revenue mobilization: The case of Edo State in Nigeria. World Bank's Macroeconomics \& Fiscal Management Practice Note No. 9.

Kalb, A. (2010). The impact of intergovernmental grants on cost efficiency: Theory and evidence from German municipalities. Economic Analysis and Policy, 4a1), 23-48.

Kauder, B., Potrafke, N., \& Reischmann, M. (2016). Do politicians reward core supporters? Evidence from a discretionary grant program. European Journal of Political Economy, 45(C), 39-56.

Khemani, S. (2015). Buying votes vs. supplying public services political incentives to under-invest in propoor policies. Journal of Development Economics, 117(January), 84-93.

Kleibergen, F., \& Paap, R. (2006). Generalized reduced rank tests using the singular value decomposition. Journal of Econometrics, 133(1), 97-126.

Lago-Peñas, S. (2008). Local governments' asymmetric reactions to grants: Causes and consequences. Public Finance Review, 36(2), 219-242.

LeVan, A. C. (2015). Dictators and democracy in African development: The political economy of good governance in Nigeria. New York: Cambridge University Press. 
Masaki, T. (2018). The impact of intergovernmental transfers on local revenue generation in Sub-Saharan Africa: Evidence from Tanzania. World Development, 106(C), 173-186.

Mogues, T., \& Benin, S. (2012). Do external grants to district governments discourage own revenue generation? a look at local public finance dynamics in Ghana. World Development, 4a5), 1054-1067.

Musgrave, R. A. (1999). Fiscal federalism. In J. M. and Buchanan \& R. A. Musgrave (Eds.), Public Finance and Public Choice (pp. 155-202). Cambridge, Mass.: The MIT Press.

Oates, W. E. (1972). Fiscal federalism. New York: Harcourt Brace Jovanovich.

Oates, W. E. (1999). An essay on fiscal federalism. Journal of Economic Literature, 373), 1120-1149.

Oates, W. E. (2007). On the theory and practice of fiscal decentralization. CREI Working Paper No . 1/ 2007, (1), 1-20.

Phillips, A. (1971). Nigeria's federal financial experience. The Journal of Modern African Studies, 93), 389408.

Phillips, A. O. (1991). Managing fiscal federalism: Revenue allocation issues. Publius: The Journal of Federalism, 21(4), 103-111.

Phillips, A. O. (1997). Nigeria's fiscal policy, 1980-2010 (NISER Monograph No. 17). Ibadan: Nigerian Institute of Social and Economic Research.

Prud'homme, R. (1995). The dangers of decentralization Document View. The World Bank Research Observer, 192), 201-220.

Reinikka, R., \& Svensson, J. (2004). Local capture: Evidence from a central government transfer program in Uganda. The Quarterly Journal of Economics, 119(2), 679-705.

Roodman, D. (2009a). A note on the theme of too many instruments. Oxford Bulletin of Economics and Statistics, 71(1), 135-158.

Roodman, D. (2009b). How to do xtabond2: An introduction to difference and system GMM in Stata. The Stata Journal, 91), 86-136.

Smoke, P., Loffler, G., \& Bosi, G. (2013). The role of decentralisation/devolution in improving development outcomes at the local level: Review of the literature and selected cases. Brooklyn, NY: Local Development International LLC.

Sobel, R. S., \& Crowley, G. R. (2014). Do intergovernmental grants create ratchets in state and local taxes? Public Choice, 158(1-2), 167-187.

Staiger, D., \& Stock, J. H. (1997). Instrumental variables regression with weak instruments. Econometrica, 65(3), 557-586.

The Federal Republic of Nigeria. (2011). The 1999 Constitution of the Federal Republic of Nigeria as amended 2010.

Troland, E. (2016). Can fiscal transfers increase local revenue collection? Evidence from the Philippines. SSRN Electronic Journal.

Veiga, L. G. (2012). Determinants of the assignment of EU funds to Portuguese municipalities. Public Choice, 153(1-2), 215-233.

White, H. (1980). A heteroskedasticity-consistent covariance matrix estimator and a direct test for heteroskedasticity. Econometrica, 48(4), 817-838.

Wilde, J. A. (1968). The expenditure effects of grant-in-aid programs. National Tax Journal, 21(3), 340-348.

Windmeijer, F. (2005). A finite sample correction for the variance of linear efficient two-step GMM estimators. Journal of Econometrics, 126(1), 25-51.

Wooldridge, J. (2010). Econometric analysis of cross-section and panel data, 2nd ed. Cambridge, Mass.: The MIT Press.

Zhang, G. (2013). The Impacts of Intergovernmental Transfers on Local Governments' Fiscal Behavior in China: A Cross-County Analysis. Australian Journal of Public Administration, 72(3), 264-277.

Zhuravskaya, E. V. (2000). Incentives to provide local public goods: fiscal federalism, Russian style. Journal of Public Economics, 76(3), 337-368. 


\section{Appendix A}

Table A1: Revenue Assignment

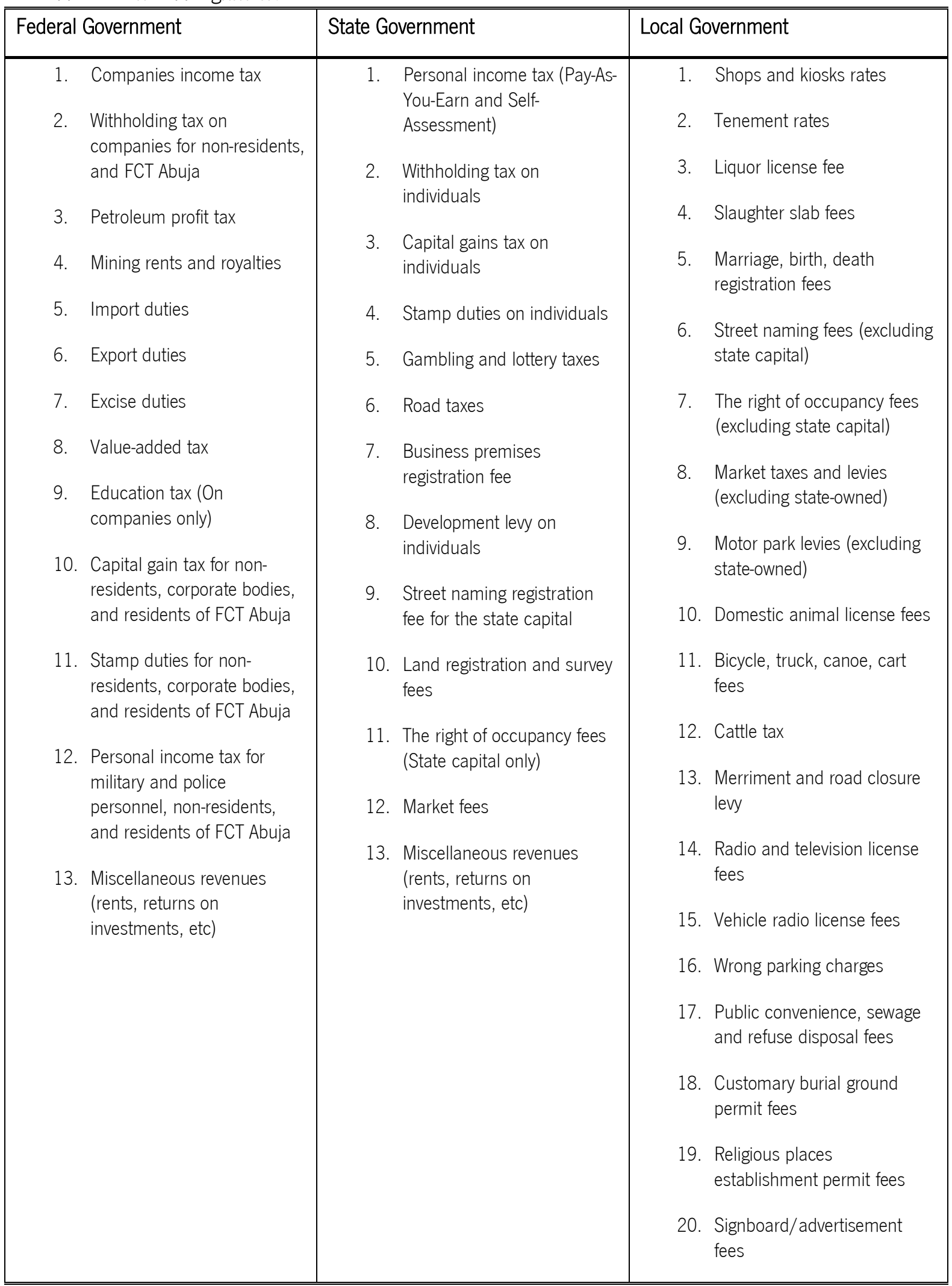

Notes: The table contains information on revenue-raising powers of each tier of the government of the federation in Nigeria as defined by the 1999 Constitution of the Federal Republic of Nigeria. See section 3 for detailed discussion. According to the table, the federal government is left with the most productive sources of revenues. Each tier of government collects taxes as laid down in the constitution and presented in the table. But, for taxes like PAYE, Capital Gain Tax, and Stamp Duties, the federal government retains jurisdiction over legislation while the administration is shared with states. Source: Phillips (1997) with addition from the author. 
Table A2: Vertical Revenue Allocation formulae in Nigeria, 1981-2004 (in percentage, \%)

\begin{tabular}{|c|c|c|c|c|c|c|c|c|c|c|c|}
\hline Recipient & 1981 & 1984 & 1989 & 1990 & 1991 & $1992^{\circ}$ & $1992^{c}$ & 1999 & $2002^{d}$ & $2002^{e}$ & 2004 \\
\hline Federal government & 55 & 55 & 47 & 50 & 47.5 & 50 & 48.5 & 48.5 & $\underline{56}$ & $\underline{54.68}$ & $\underline{52.68}$ \\
\hline Special Funds & 4.5 & 2.5 & 8 & 5 & 10 & 5 & 7.5 & 7.5 & 7.5 & 6.185 & 4.18 \\
\hline 1. FCT & - & - & 1 & 1 & 1 & 1 & 1 & 1 & 1 & 1 & 1 \\
\hline 2. Stabilisation & - & - & 0.5 & 0.5 & 0.5 & 0.5 & 0.5 & 0.5 & 1.5 & 0.725 & 0.5 \\
\hline 3. Derivation & 2 & - & 2 & 1 & 1 & 1 & 1 & 1 & - & - & - \\
\hline 4. Dev. of MP Areas & 1.5 & 1.5 & 2 & 1.5 & 1.5 & 1.5 & 3 & 3 & - & - & - \\
\hline 5. General Ecology & 1 & 1 & 0.5 & 1 & 1 & 1 & 2 & 2 & 2 & $1.46^{4}$ & 1 \\
\hline 6. Pry Education Fund & - & - & - & - & 5 & - & - & - & - & - & - \\
\hline 7. Dev. of NMP Areas & - & - & 0.5 & - & - & - & - & - & - & - & - \\
\hline 8. Savings & - & - & 2 & - & - & - & - & - & - & - & - \\
\hline 9. Dev. of Nat. Resources & - & - & - & - & - & - & - & - & 3 & 3 & 1.68 \\
\hline State Governments & 30.5 & $32.5^{a}$ & 30 & 30 & 28.5 & 24 & 24 & 24 & 24 & 24.72 & 26.72 \\
\hline Local Governments & 10 & 10 & 15 & 15 & 14 & 20 & 20 & 20 & 20 & 20.60 & 20.60 \\
\hline Total & 100 & 100 & 100 & 100 & 100 & 100 & 100 & 100 & 100 & $100^{8}$ & 100 \\
\hline $\begin{array}{l}\text { denotes vertical allocation formulae } \\
2 \% \text { of the mineral component of the } \\
\text { b.c.de. denote implemented allocation fo } \\
\text { From July } 2002 \text {, the special allocatio } \\
\text { :The total due to the federal governm } \\
\text { Also, since May 2002, all the special } \\
\text { MP and NMP imply mineral producing }\end{array}$ & $\begin{array}{l}\text { Imended by } \\
32.5 \% \text { due } \\
\text { e by the fed } \\
\text { omes feder } \\
\text { as approxim } \\
\text { tions are pa } \\
\text { s and non- }\end{array}$ & $\begin{array}{l}\text { MAFC but } \\
\text { tes from th } \\
\text { overnment } \\
\text { rnment sh } \\
54.68 \% . \\
\text { he federal } \\
\text { al producir }\end{array}$ & $\begin{array}{l}\text { ary } 1992 \\
\text { erivation } \\
\text { ent's sha } \\
\text { respectii }\end{array}$ & $\begin{array}{l}\text { ented. } \\
\text { to be share } \\
1992 \text {, May } \\
\text { ology. }\end{array}$ & $\begin{array}{l}\text { d on the } \\
\text { and July }\end{array}$ & $\begin{array}{l}\text { principle. } \\
\text { orders. }\end{array}$ & & & & & \\
\hline
\end{tabular}


Table A3: Horizontal Revenue Sharing Formula (\%)

The basis of Sharing

Percentage of Total Fund

Equality:

40

Population:

30

Landmass and Terrain:

10

Landmass

5

Terrain

5

\section{Social Development Factors:}

Education

Primary school enrolment

Secondary/Commercial school enrolment

Inverse secondary/commercial school enrolment

Health

Hospital beds

Hospital beds inverse proportion

$\underline{\text { Water }}$

Water supply spread

Rainfall inverse proportion

Internal Revenue Effort:

Total

Notes: The variables in the table determine transfers allocation at a horizontal level in Nigeria. The formula has remained the same since the advent of the fourth republic in 1999. What each state of the federation gets is determined by the parameters defined in the table. This formula is applied to vertical allocation to all states to determine what each state will get (see column 12 of Table A2 for state governments' share of vertical allocation). Bird and Smart (2002) caution against the use of a measure of fiscal effort in allocation formula (See the article for a detailed discussion). Until 2010, revenue efforts of state governments were not published in Nigeria. Currently, there is no publicly available data on internal revenues of the 774 local government areas. Yet, they receive transfers just like state governments from the federal government. Hence, it is difficult to say the own revenue effort is applied in revenue sharing in Nigeria. Source: Author's compilation. 